\title{
Determination of seventeen endocrine disruptor compounds and their spatial and seasonal distribution in Ria Formosa Lagoon (Portugal)
}

\author{
Maria João Rocha $\cdot$ Catarina Cruzeiro • \\ Mário Reis • Eduardo Rocha $\cdot$ Miguel Pardal
}

Received: 26 June 2012 / Accepted: 6 March 2013 / Published online: 18 April 2013

(C) Springer Science+Business Media Dordrecht 2013

\begin{abstract}
In spite of its outstanding ecological and touristic importance the Ria Formosa Lagoon shows signs of anthropogenic pollution. Nonetheless, until the present survey no studies had ever documented the measurement of natural and pharmaceutical estrogens (17 $\beta$-estradiol, estrone, and $17 \alpha$-ethynylestradiol), xenoestrogenic industrial pollutants (4-octylphenol, 4nonylphenol, and their mono and diethoxylates and bisphenol A), phytoestrogens (formononetin, biochanin A, daidzein, genistein), and sitosterol in this area. The 17 compounds measured herein are known as endocrine disrupters (EDCs) and act over the endocrine system even in few amounts $\left(\mathrm{ng} \mathrm{L}^{-1}-\mu \mathrm{g} \mathrm{L}^{-1}\right)$. Thus to conclude
\end{abstract}

M. J. Rocha $\cdot$ C. Cruzeiro $\cdot$ E. Rocha

Laboratory of Cellular, Molecular and Analytical Studies, Interdisciplinary Centre for Marine and Environmental Research (CIIMAR), CIMAR Associate Laboratory (CIMAR LA), University of Porto (UPorto), Oporto, Portugal

M. J. Rocha $(\bowtie)$

CESPU, Superior Institute of Health Sciences-North

(ISCS-N), Gandra, Paredes, Portugal

e-mail: mjsrocha@netcabo.pt

M. J. Rocha $\cdot$ E. Rocha

Laboratory of Histology and Embryology, Institute of Biomedical Sciences Abel Salazar (ICBAS), UPorto, Oporto, Portugal

M. Reis $\cdot$ M. Pardal

CFE - Centre for Functional Ecology, Department of Life

Sciences, University of Coimbra, Apartado 3046,

3001-401 Coimbra, Portugal about the influx of EDCs in the lagoon, water samples were taken every 2 months, during 1 year (2010), in low tide at nine sites distributed along the coastline. Water samples (1 L) were preconcentrated in the Oasis HLB cartridges and cleaned in silica cartridges before their analysis by GC-MS. Data showed the ubiquitous presence of potentially hazardous amounts of estrogens (particularly of ethynylestradiol, up to $24.3 \mathrm{ng} \mathrm{L}^{-1}$ ), nonylphenol (up to $547 \mathrm{ng} \mathrm{L}^{-1}$ ), and sitosterol (up to $12,300 \mathrm{ng} \mathrm{L}^{-1}$ ), mainly in summer, suggesting that the increase of the local number of inhabitants (tourists), the rise of the water temperature (up to $26^{\circ} \mathrm{C}$ ), and the blooming of local flora may interfere with the water quality parameters. This makes the lagoon a potential model to study. Taking into account the data, it was concluded that there are conditions for the occurrence of endocrine disruption in aquatic animals, even in areas included in the natural park of the Formosa. Besides, both the high amounts of un-ionized ammonia (up to 0.3 $\mathrm{mg} \mathrm{L}^{-1}$ ) and phosphates (up to $1.6 \mathrm{mg} \mathrm{L}^{-1}$ ) my pose risks for local fauna and humans.

Keywords Estrogens · Alkylphenols · Alkylphenol ethoxylates $\cdot$ Phytoestrogens $\cdot$ Sitosterol

\section{Introduction}

The Ria Formosa is a shallow mesotidal lagoon in the South Portuguese coast with about $60 \mathrm{~km}$ length and an area of $160 \mathrm{~km}^{2}$. Here, $50 \%$ to $75 \%$ of the water is replaced each tide by the Atlantic Ocean 
(Newton and Mudge 2003). The lagoon is formed by many small islands and inlets and due to its remarkable natural resources it is a vast natural protected area, but with an intense touristic activity - according to figures from the "Ports and Maritime Transport Institute (IPTM)" approx. 1.88 million passengers travelled on the Ria Formosa ferries from January to December 2010 (Calixto et al. 2011). Besides this, accordingly to the Portuguese Water Institute (INAG) and the Institute of Marine Research (IMAR) (Ferreira 2003), the Ria Formosa lagoon is also highly impacted by the discharge of effluents coming from 28 domestic and industrial wastewater treatment plants (WWTP), the presence of household effluents without wastewater treatment and non-point sources such as rainfall runoff (Ferreira 2003). Economically, and besides tourism, this area is also a very dynamic region in terms of food processing industries and bivalve production. Unfortunately, due to the above referred anthropogenic pressure, important signs of local pollution and endocrine disruption of several aquatic species have already been reported in this lagoon (Bebianno and Barreira 2009; Carvalho et al. 2009; Vasconcelos et al. 2010; David et al. 2009; Bebianno et al. 2004). Thus, in spite of the presence of local fecal contamination (Dionisio et al. 2000; Gamito 2008; Mudge et al. 1999) and the knowledge about the presence of industrial effluents, until the moment, the levels of natural and pharmaceutical estrogens, alkylphenols (APs) and alkylphenol polyethoxylates (APEOs) - chemicals included in the group of "priority substances in the field of water policy"-were never evaluated in the Ria Formosa Lagoon. We hypothesize that such compounds do exist and reach biologically significant amounts in the lagoon waters. Despite the high water turnover at each tide, several studies reported eutrophication and hypoxia, mainly in summer at some spots of the lagoon (Newton and Mudge 2005; Newton et al. 2010); however, no information exists about the presence of either phytoestrogens or the annual fluctuation patterns of sitosterol. These compounds in spite of being of natural/vegetal sources, in high amounts phytoestrogens and sitosterol, are known to act as endocrine disrupter compounds (EDCs; Hoerger et al. 2009; Clotfelter et al. 2010). Thus, beyond the last compounds, the present study aimed to provide the first data for the Ria Formosa Lagoon about the levels of several of the most concerning worldwide anthropogenic/industrial EDCs such as estradiol, estrone, ethynylestradiol, 4-n-octylphenol, 4-toctylphenol, nonylphenol, several polyethoxylates (4-octylphenol monoethoxylate, 4-octylphenol diethoxylate, 4-nonylphenol monoethoxylate, 4nonylphenol diethoxylate), and bisphenol A. Besides monitoring, seasonal trends were also investigated for phytoestrogens (formononetin, biochanin A, daidzein, genistein) and sitosterol. The study was conducted at nine important locations distributed along the Ria Formosa Lagoon, by gas chromatography coupled to mass spectroscopy (GC-MS). Additionally, several physicochemical quality parameters, linked with the presence of fecal contamination and eutrophication, such as dissolved oxygen, $\mathrm{pH}$, nitrates, nitrites, ammonia, un-ionized ammonia, and phosphates were measured. The data are relevant not only locally, but it also contributes to the global picture being built in all the Iberian Peninsula concerning the amounts and types of EDCs polluting surface water, filling in the case gaps of information for southwestern Europe.

\section{Materials and methods}

Study area

The Ria Formosa Lagoon is a barrier island system comprising five islands, two peninsulas and six inlets stretching along the Algarve coastline. Due to its extension (approx. $60 \mathrm{~km}$ ), 9 sampling stations (S1 to S9, Fig. 1) were selected along the coast covering several urban centres and the natural park protected area. Thus, S1 to S3 (Zone I) hold the Ludo natural area, the city of Faro with ca. 58,300 inhabitants and the city of Olhão with ca. 42,300 inhabitants; S4 to S6 (Zone II) comprise the wildest/major fraction of the Ria Formosa natural park, which is constituted by a complex system of dunes, inlets, salt marshes, mudflats, sand flats, and a small mainland area; S7 to S9 (Zone III) embraced the Tavira city, ca. 58,300 inhabitants (Fig. 1). The water circulation patterns of the lagoon encircle together Zones I and II, whereas, Zone III is submitted to other currents (Duarte et al. 2008).

\section{Chemicals and materials}

Analytical grade of anhydrous pyridine, $\mathrm{N}, \mathrm{O}$ bis(trimethylsilyl)trifluoroacetamide (BSTFA) added with $1 \%(w / v)$ trimethylchlorosilane (TMCS), and hexane, were supplied by Sigma-Aldrich (Steinheim, Germany). Dichloromethane and methanol were acquired from Romil Ltd. (Cambridge, 
Fig. 1 Location of the sampling sites within the Ria Formosa Lagoon (S1 to S9), Algarve, Portugal. (Microsoft MapPoint 2010)

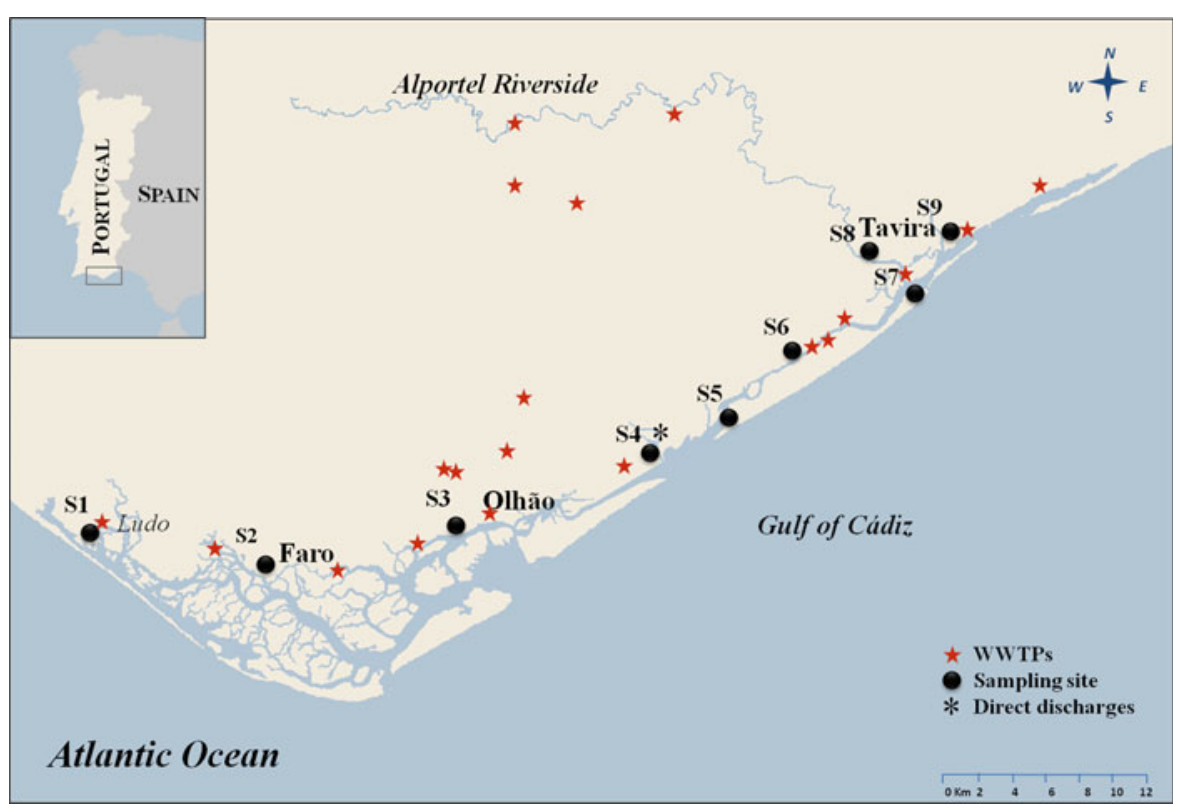

UK). The SPE cartridges, $200 \mathrm{mg}$ Oasis HLB (Hydrophilic-Lipophilic Balance), $6 \mathrm{cc}$, were acquired from Waters Corporation (Milford, MA, USA) and 1,000 mg silica cartridges, $6 \mathrm{cc}$, were purchased from Teknokroma (Barcelona, Spain). Ultrapure water was supplied by a Milli-Q water system (conductivity= $0.054 \mu \mathrm{S} / \mathrm{cm}$, at $25^{\circ} \mathrm{C}$ ). Estrone (E1), $17 \beta$-estradiol (E2), $17 \alpha$-ethynylestradiol (EE2), $17 \beta$-estradiol- $\mathrm{d}_{2}$ (E2-d $\mathrm{d}_{2}$ ), 4-t-octylphenol (4-t-OP), 4-n-octylphenol (4-OP), bisphenol A (BPA), bisphenol A-d ${ }_{16}$ (BPA$\mathrm{d}_{16}$ ), Igepal CA-210 (4-octylphenol monoethoxylate, OP1EO and 4-octylphenol diethoxylate, OP2EO), and Igepal CO-210 (4-nonylphenol monoethoxylate, NP1EO and 4-nonylphenol diethoxylate, NP2EO), formononetin (FORM), biochanin A (BIO-A), daidzein (DAID), genistein (GEN), and sitosterol (SITO) were obtained from Sigma-Aldrich (Steinheim, Germany). 4-Nonylphenol (4-n-NP) and nonylphenol isomers (NP) were supplied from Riedel-deHaën (Seelze-Hannover, Germany). Stock solutions of individual standards $\left(100 \mathrm{mg} \mathrm{L}^{-1}\right)$ were prepared in methanol, transferred to amber bottles and stored in the dark at $-20^{\circ} \mathrm{C}$.

Water collection and in situ measurements

Throughout 2010 and using a peristaltic pump (Global Water, Model: WS300), the water samples were collected in low tide, at $1 \mathrm{~m}$ depth, in winter (10th February), spring (15th April), summer (23th June and 19th August), and autumn (12th October and 15th December). During sampling, all bottles were rinsed three times before the collection. Physicochemical parameters as temperature, $\mathrm{pH}$, dissolved oxygen, and conductivity were evaluated, in situ, by the portable meters LF 330/Set WTW, pH 330i/Set WTW, and OXi 330i/Set WTW, respectively. During transport to laboratory, all flasks were stored at $c a .5{ }^{\circ} \mathrm{C}$. Then, samples were immediately filtrated using $0.45 \mu \mathrm{m}$ glass fibre filters (Millipore, Ireland) to eliminate particulate matter and other suspended solids. All filtrates were then acidified with $\mathrm{H}_{2} \mathrm{SO}_{4}$ to $\mathrm{pH} 2$ and then subjected to solid phase extraction (SPE) within a maximum period of $48 \mathrm{~h}$.

Sample preparation

All 17 EDCs (Fig. 2) were extracted by SPE using OASIS HLB cartridges adapted in an off-line SPE vacuum extraction device (Waters). The breakthrough volume, $\mathrm{pH}$ adjustment with $\mathrm{H}_{2} \mathrm{SO}_{4}$ to $\mathrm{pH} 2$, washes and elution conditions followed a previous methods developed by our group (Rocha et al. 2011; Ribeiro et al. 2007). Briefly, the condition step was carried out with $10 \mathrm{~mL}$ of $\mathrm{CH}_{2} \mathrm{Cl}_{2}: \mathrm{CH}_{3} \mathrm{OH}(50: 50, v / v)$, to remove residual bonding agents, followed by $6 \mathrm{~mL}$ of $\mathrm{CH}_{3} \mathrm{OH}$ and $13 \mathrm{~mL}$ of ultrapure water, at a flow rate of 1 $\mathrm{mL} / \mathrm{min}$. Water samples $(1 \mathrm{~L})$ added with $\mathrm{E} 2-\mathrm{d}_{2}$ and BPA-d $\mathrm{d}_{16}$ (deuterated surrogates, herein used also as 
Fig. 2 Chemical structure of the seventeen EDCs analyzed in superficial waters of Ria Formosa Lagoon

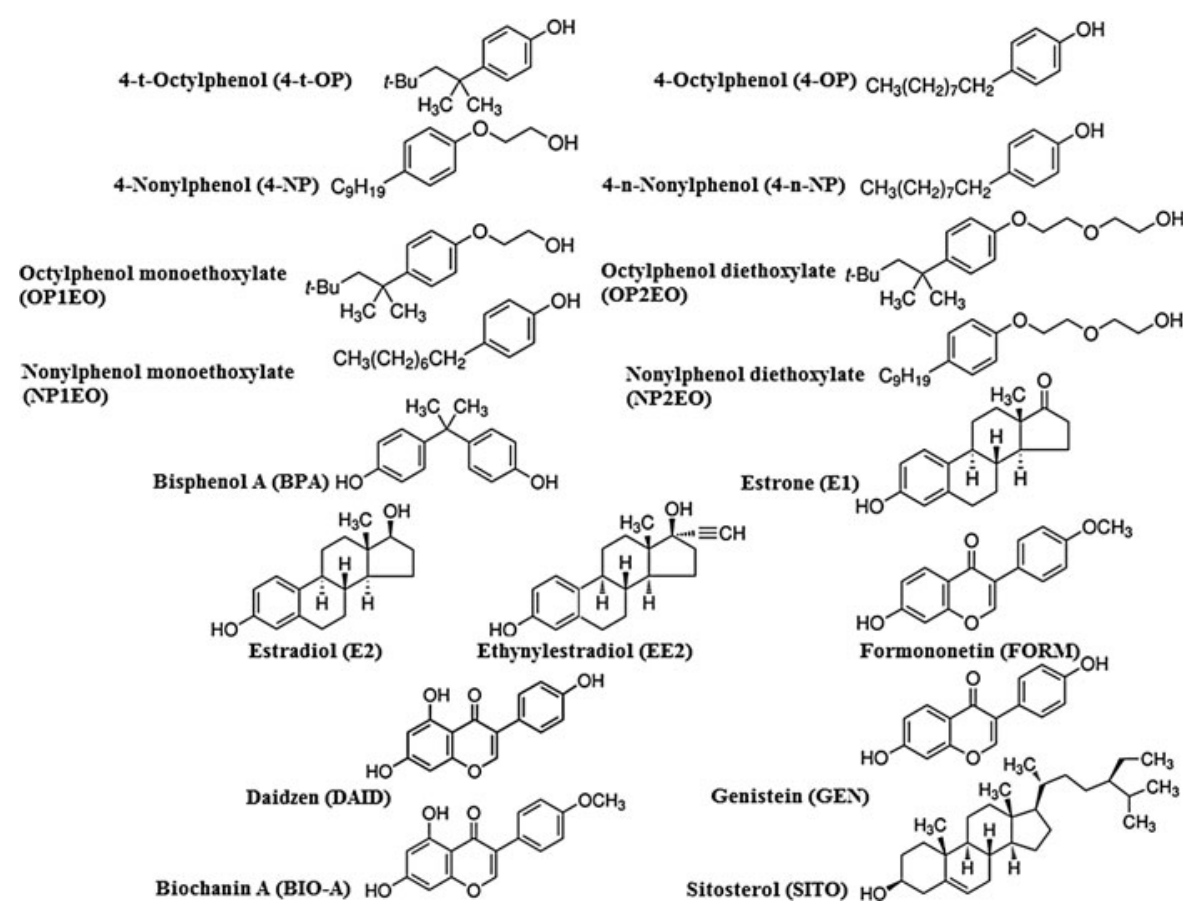

internal standards, IS), were loaded on top of SPE cartridges at a constant flow rate of $5 \mathrm{~mL} / \mathrm{min}$ followed by a washing step with $13 \mathrm{~mL}$ of ultrapure water and $1 \mathrm{~mL}$ of $\mathrm{CH}_{3} \mathrm{OH}$. Cartridges were dried under vacuum for $30 \mathrm{~min}$ and then eluted with 10 $\mathrm{mL}$ of $\mathrm{CH}_{2} \mathrm{Cl}_{2}: \mathrm{CH}_{3} \mathrm{OH}(50: 50, v / v)$. Because the eluted extracts were sticky and dark, they needed to be cleaned before analysis. The cleaning step was achieved using silica cartridges $(1 \mathrm{~g})$. Then, the final extracts were evaporated to dryness in a heating block at $36{ }^{\circ} \mathrm{C}$ under a gentle $\mathrm{N}_{2}$ stream and reconstituted with $250 \mu \mathrm{L}$ of anhydrous methanol-the sample concentration factor was 4,000-fold.

\section{Quantification by GC-MS}

GC-MS analysis was performed using a gas chromatograph (Trace GC ultra, Thermo Finnigan Electron Corporation) coupled with an ion trap mass spectrometer

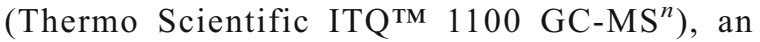
autosampler (Thermo Scientific TriPlus ${ }^{\mathrm{TM}}$ ) and a TR5MS capillary column $(30 \mathrm{~m} \times 0.25 \mathrm{~mm}$ i.d., $0.25 \mu \mathrm{m}$ film thickness). Helium carrier gas (99.9999 \% purity) was maintained at a constant flow rate of $1.0 \mathrm{~mL} \mathrm{~min}$. Column oven temperatures were programmed using several ramps: a) from $100{ }^{\circ} \mathrm{C}$ (initial equilibrium time 1 min) to $200^{\circ} \mathrm{C}$ at $10^{\circ} \mathrm{C} \mathrm{min}^{-1}$; b) from $200{ }^{\circ} \mathrm{C}$ to $260^{\circ} \mathrm{C}$ at $6{ }^{\circ} \mathrm{C} \mathrm{min}-1$; and, finally c) from $260{ }^{\circ} \mathrm{C}$ to $290{ }^{\circ} \mathrm{C}$ at $1{ }^{\circ} \mathrm{C} \min ^{-1}$, at this point the $\mathrm{GC}$ oven was maintained at $290{ }^{\circ} \mathrm{C}$ for $5 \mathrm{~min}$. A solvent delay time of $8.5 \mathrm{~min}$ was used to protect the ion multiplier of the MS instrument from saturation. Temperatures of PTV liner ranged from $35{ }^{\circ} \mathrm{C}$ to $250{ }^{\circ} \mathrm{C}$ via a ramp of $10{ }^{\circ} \mathrm{C} \mathrm{s}^{-1}$. Both MS transfer line and ion source were at $280{ }^{\circ} \mathrm{C}$. Sample injection $(3 \mu \mathrm{L})$ was programmed in splitless mode using an 80-mm injection needle. Quantitative analysis was performed in a selected ion monitoring mode (SIM) using external calibration. Working solutions were prepared diluting the stock solution with methanol at six calibration levels ranging from $10-375 \mathrm{ng} \mathrm{L}^{-1}$ for all seventeen EDCs and $50 \mathrm{ng} \mathrm{L}^{-1}$ of each IS. The analytic parameters about the used GC-MS method are summarized in Table 1. Since the current EDCs were measured in $n \mathrm{~L}^{-1}$, method blanks were used to ensure the absence of contamination by laboratory material. Beyond this, unbiased water samples were spiked with all assayed EDCs at an intermediate concentration (150 ng $\mathrm{L}^{-1}$ ) of the calibration curve and then submitted to usual analysis.

Statistical analysis

Accordingly to the geographical conditions and water currents, sampling sites were grouped in three zones. 
Table 1 Quantification, diagnostic ions, and limits of quantification (LOQ) of each compound analyzed by GC-MS
Inside brackets is referred to the relative abundance of ions $(\mathrm{m} / \mathrm{z})$ for each target EDC

\begin{tabular}{lllll}
\hline EDCs & $\begin{array}{l}\text { tr } \\
(\mathrm{min})\end{array}$ & $\begin{array}{l}\text { Quantification } \\
(\mathrm{m} / z)\end{array}$ & $\begin{array}{l}\text { Diagnostic ions } \\
(\mathrm{m} / z)\end{array}$ & $\begin{array}{l}\text { LOQ } \\
\left(\mathrm{ng} \mathrm{L}^{-1}\right)\end{array}$ \\
\hline 4-t-OP & 10.54 & $207(100)$ & - & 4.8 \\
4-NP & $11.0-12.2$ & $207(100)$ & $179(84.9), 193(31.9), 221(31.9)$ & 18.1 \\
4-n-OP & 12.7 & $179(100)$ & $180(17.7)$ & 11.6 \\
OP1EO & 14.9 & $179(100)$ & $207(97.2), 135(68.9)$ & 17.5 \\
NP1EO & $15.8-16.3$ & $251(100)$ & $265(64.4), 207(59.5), 135(45.5)$ & 6.1 \\
BPA-d16 & 17.6 & $368(100)$ & $369(34.7), 386(9.1)$ & - \\
BPA & 17.8 & $357(100)$ & $358(30.8)$ & 2.4 \\
OP2EO & 18.3 & $295(100)$ & $207(76.5), 115(55.2)$ & 3.1 \\
NP2EO & $19.4-20.4$ & $295(100)$ & $207(74.9)$ & 6.8 \\
E1 & 24.3 & $342(100)$ & $357(55.1)$ & 3.2 \\
E2-d2 & 24.4 & $287(100)$ & $418(75.2), 328(72.8)$ & - \\
E2 & 24.4 & $285(100)$ & $416(85.2), 326(48.4)$ & 4.4 \\
EE2 & 27.2 & $425(100)$ & $285(48.0), 426(34.7)$ & 8.6 \\
FORM & 28.5 & $340(100)$ & $339(76.0), 355(22.6)$ & 4.6 \\
BIO-A & 29.2 & $356(100)$ & $341(34.3)$ & 4.1 \\
DAID & 29.9 & $398(100)$ & $383(76.0), 355(22.6)$ & 3.8 \\
GEN & 31.7 & $471(100)$ & $473(19.9)$ & $486(53.4), 255(49.4)$ \\
SITO & 42.1 & $396(100)$ & & \\
\hline & & & &
\end{tabular}

\section{Results}

\section{Estrogens}

In all analyzed samples the frequency of occurrence of E1, E2, and EE2 was $\approx 100 \%$. In Fig. 3 it is shown the spatial and seasonal fluctuation patterns of the last compounds and in Table 2 it is reported the mean levels, per zone, of E1, E2 and EE2. Comparing the zones it was observed that the concentrations of $\sum$ Estrogens were 34 ng $\mathrm{L}^{-1}$ at Zone I, in spring, and about $30 \mathrm{ng} \mathrm{L}^{-1}$ at both Zones II and III, in summer. Thus, no differences were found among zones neither for the $\sum$ Estrogens nor for the individual levels of E1, E2, and EE2 $(p>0.05)$. for $p<0.05$ (two-tailed analysis).
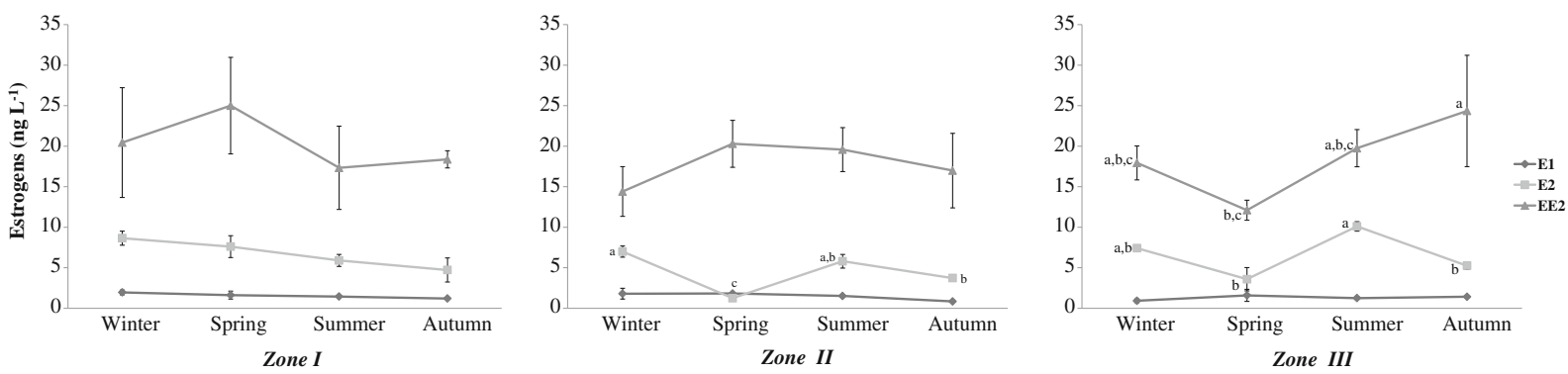

Fig. 3 Spatial and seasonal fluctuations of E1, E2 and EE2 at Zones I, II and III of Ria Formosa Lagoon. Data is shown as mean \pm standard error of the mean (SE); $n=3$ for each zone in winter and spring and $n=6$ in summer and autumn 
Table 2 Environmental levels of all EDCs measured in River Formosa Lagoon from February to December 2010

\begin{tabular}{|c|c|c|c|c|}
\hline $\begin{array}{l}\text { EDCs } \\
\left(\text { ng L }^{-1}\right)\end{array}$ & Winter & Spring & Summer & Autumn \\
\hline \multicolumn{5}{|l|}{ Zone I } \\
\hline 4-t-OP & $8.6 \pm 1.3$ & $11.5 \pm 1.3$ & $13.3 \pm 2.7$ & $18.6 \pm 2.4$ \\
\hline 4-NP & $17.8 \pm 2.6$ & $474 \pm 97$ & $450 \pm 106$ & $206 \pm 41$ \\
\hline 4-OP & $3.6 \pm 0.5$ & $2.0 \pm 0.5$ & $2.2 \pm 0.7$ & $7.4 \pm 2.8$ \\
\hline 4-n-NP & $14.6 \pm 2.1$ & $4.5 \pm 1.1$ & $4.5 \pm 1.4$ & $5.6 \pm 2.6$ \\
\hline BPA & $30 \pm 9$ & $17.7 \pm 7.9$ & $14.3 \pm 4.6$ & $16.2 \pm 2.9$ \\
\hline OP1EO & $17.0 \pm 2.5$ & $36 \pm 27$ & $9.4 \pm 3.3$ & $13.4 \pm 1.4$ \\
\hline NP1EO & $171 \pm 25$ & $279 \pm 150$ & $135 \pm 89$ & $76 \pm 3$ \\
\hline OP2EO & $82 \pm 12$ & $182 \pm 90$ & $152 \pm 70$ & $46 \pm 11$ \\
\hline NP2EO & $99 \pm 23$ & $749 \pm 128$ & $780 \pm 212$ & $166 \pm 29$ \\
\hline E1 & $2.0 \pm 0.3$ & $1.6 \pm 0.5$ & $1.4 \pm 0.1$ & $1.2 \pm 0.1$ \\
\hline $\mathrm{E} 2$ & $8.7 \pm 0.9$ & $7.6 \pm 1.3$ & $5.9 \pm 0.7$ & $4.7 \pm 1.5$ \\
\hline EE2 & $20 \pm 7$ & $25 \pm 6$ & $17.3 \pm 5.1$ & $18.4 \pm 1.1$ \\
\hline FORM & $963 \pm 320$ & $450 \pm 55$ & $1041 \pm 333$ & $186 \pm 30$ \\
\hline BIO-A & $256 \pm 36$ & $144 \pm 41$ & $91 \pm 3$ & $102 \pm 17$ \\
\hline DAID & $9.5 \pm 0.4$ & $14.0 \pm 3.9$ & $9.5 \pm 0.8$ & $6.7 \pm 0.7$ \\
\hline GEN & $898 \pm 381$ & $408 \pm 50$ & $1157 \pm 347$ & $556 \pm 41$ \\
\hline SITO & $538 \pm 67$ & $5608 \pm 1287$ & $6192 \pm 1204$ & $2107 \pm 123$ \\
\hline \multicolumn{5}{|l|}{ Zone II } \\
\hline 4-t-OP & $5.9 \pm 0.3$ & $41 \pm 36$ & $11.6 \pm 1.1$ & $15.7 \pm 3.0$ \\
\hline 4-NP & $12.2 \pm 0.7$ & $192 \pm 57$ & $511 \pm 94$ & $164 \pm 20$ \\
\hline 4-OP & $2.5 \pm 0.1$ & $0.5 \pm 0.1$ & $2.0 \pm 0.3$ & $8.5 \pm 3.5$ \\
\hline 4-n-NP & $10 \pm 1$ & $5.5 \pm 1.5$ & $6.1 \pm 1.2$ & $5.0 \pm 2.4$ \\
\hline BPA & $24 \pm 3$ & $20 \pm 4$ & $29 \pm 9.5$ & $25 \pm 6$ \\
\hline OP1EO & $11.7 \pm 0.6$ & $7.3 \pm 1.6$ & $7.9 \pm 0.3$ & $10.7 \pm 1.8$ \\
\hline NP1EO & $117 \pm 6$ & $81 \pm 27$ & $79 \pm 17$ & $65 \pm 19$ \\
\hline OP2EO & $56 \pm 3$ & $76 \pm 28$ & $71 \pm 6$ & $58 \pm 26$ \\
\hline NP2EO & $49 \pm 6$ & $543 \pm 65$ & $678 \pm 62$ & $237 \pm 134$ \\
\hline E1 & $1.8 \pm 0.7$ & $1.8 \pm 0.2$ & $1.5 \pm 0.2$ & $0.9 \pm 0.1$ \\
\hline E2 & $7.0 \pm 0.7$ & $1.2 \pm 0.3$ & $5.8 \pm 0.8$ & $3.7 \pm 0.4$ \\
\hline EE2 & $14.4 \pm 3.1$ & $20 \pm 3$ & $19.6 \pm 2.7$ & $17.0 \pm 4.6$ \\
\hline FORM & $717 \pm 64$ & $463 \pm 118$ & $409 \pm 42$ & $270 \pm 120$ \\
\hline BIO-A & $261 \pm 35$ & $133 \pm 2.6$ & $164 \pm 42$ & $93 \pm 25$ \\
\hline DAID & $9.6 \pm 1.7$ & $4.8 \pm 3.5$ & $7.4 \pm 1.2$ & $4.6 \pm 1.0$ \\
\hline GEN & $721 \pm 132$ & $412 \pm 127$ & $497 \pm 64$ & $597 \pm 234$ \\
\hline SITO & $752 \pm 200$ & $3452 \pm 816$ & $12282 \pm 3451$ & $2512 \pm 288$ \\
\hline \multicolumn{5}{|l|}{ Zone III } \\
\hline 4-t-OP & $7.3 \pm 0.9$ & $4.3 \pm 1.3$ & $12.6 \pm 2.3$ & $27 \pm 7$ \\
\hline 4-NP & $15.1 \pm 1.8$ & $315 \pm 236$ & $547 \pm 68$ & $203 \pm 25$ \\
\hline 4-OP & $3.1 \pm 0.4$ & $1.5 \pm 0.6$ & $3.5 \pm 0.2$ & $7.8 \pm 2.3$ \\
\hline 4-n-NP & $12.4 \pm 1.5$ & $3.4 \pm 0.3$ & $9.8 \pm 2.5$ & $8.5 \pm 1.5$ \\
\hline BPA & $33 \pm 6$ & $6.5 \pm 4.7$ & $72 \pm 21$ & $69 \pm 3$ \\
\hline OP1EO & $14 \pm 2$ & $6.9 \pm 1.8$ & $10.8 \pm 2.7$ & $22 \pm 8$ \\
\hline
\end{tabular}


Table 2 (continued)

\begin{tabular}{ccccc}
\hline $\begin{array}{l}\text { EDCs } \\
\left(\text { ng L }^{-1}\right)\end{array}$ & Winter & Spring & Summer & Autumn \\
\hline NP1EO & $145 \pm 17$ & $41 \pm 9$ & $102 \pm 17$ & $121 \pm 23$ \\
OP2EO & $69 \pm 8$ & $57 \pm 11$ & $75 \pm 14$ & $83 \pm 3$ \\
NP2EO & $75 \pm 16$ & $503 \pm 85$ & $749 \pm 135$ & $474 \pm 105$ \\
E1 & $0.9 \pm 0.2$ & $1.6 \pm 0.7$ & $1.3 \pm 0.2$ & $1.4 \pm 0.1$ \\
E2 & $7.4 \pm 0.2$ & $3.6 \pm 1.4$ & $10.1 \pm 0.6$ & $5.3 \pm 0.5$ \\
EE2 & $17.9 \pm 2.1$ & $12.1 \pm 1.2$ & $19.8 \pm 2.3$ & $24 \pm 7$ \\
FORM & $455 \pm 90$ & $500 \pm 249$ & $547 \pm 145$ & $402 \pm 111$ \\
BIO-A & $207 \pm 18$ & $98 \pm 24$ & $126 \pm 15$ & $13.3 \pm 0.8$ \\
DAID & $7.2 \pm 0.9$ & $7.8 \pm 3.8$ & $589 \pm 105$ & $7.4 \pm 3.1$ \\
GEN & $405 \pm 72$ & $519 \pm 286$ & $10328 \pm 1803$ & $596 \pm 88$ \\
SITO & $572 \pm 125$ & $3486 \pm 1154$ & $2954 \pm 502$ \\
\hline
\end{tabular}

Data is presented as mean \pm standard error of the mean (SE)

Nonetheless, the global amounts of EE2 were always higher $(p<0.05)$ than those of E1 and E2. At Zone I the annual average levels of E1 $\left(\approx 1.6 \mathrm{ng} \mathrm{L}^{-1}\right)$, E2 $(\approx 6.7 \mathrm{ng}$ $\left.\mathrm{L}^{-1}\right)$, and EE2 $\left(\approx 20.3 \mathrm{ng} \mathrm{L}^{-1}\right)$ did not show any seasonal fluctuation ( $p>0.05$; Fig. 3 and Table 2$)$. At Zone II the middling levels of both E1 $\left(\approx 1.5 \mathrm{ng} \mathrm{L}^{-1}\right)$ and EE2 $\left(\approx 17.8 \mathrm{ng} \mathrm{L}^{-1}\right)$ were stable all yearlong but, by the contrary, the values of E2 decreased significantly in spring $(p<0.05$, Fig. 3$)$ reaching at that occasion values of approx. $1.2 \mathrm{ng} \mathrm{L}^{-1}$ (Table 2) which are about four times lower than that registered in the other seasons. At Zone III, it was observed a different type of seasonal fluctuation pattern for EE2, with concentrations decreasing in spring $\left(\approx 12 \mathrm{ng} \mathrm{L} \mathrm{L}^{-1} ; p<0.05\right)$ and then, rising, from summer to autumn (up to $24.3 \mathrm{ng} \mathrm{L}^{-1}$; $p<0.05$; Fig. 3). In this area the E2 levels, escort those of EE2 in spring and summer occasion when the levels of E2 were maximal $\left(\approx 10.1 \mathrm{ng} \mathrm{L}^{-1} ; p<0.05\right)$. In contrast, the levels of E1 were similar to those observed in both Zones I and II $\left(\approx 1.3 \mathrm{ng} \mathrm{L}^{-1}\right)$.
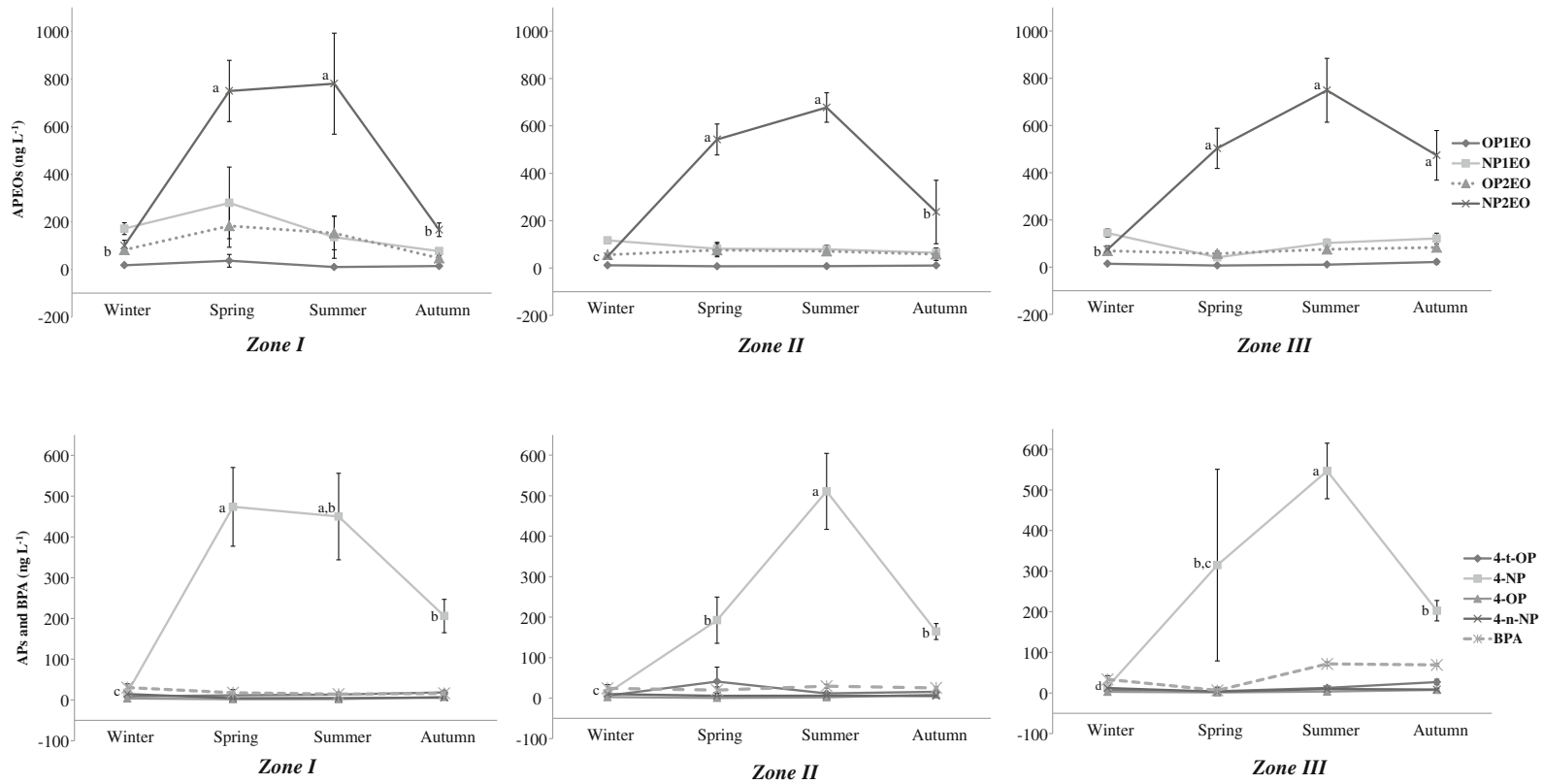

Fig. 4 Spatial and seasonal fluctuations of APEOs, APs and BPA at Zones I, II and III of Ria Formosa Lagoon. Data is shown as mean \pm standard error of the mean (SE); $n=3$ for each zone in winter and spring and $n=6$ in summer and autumn 

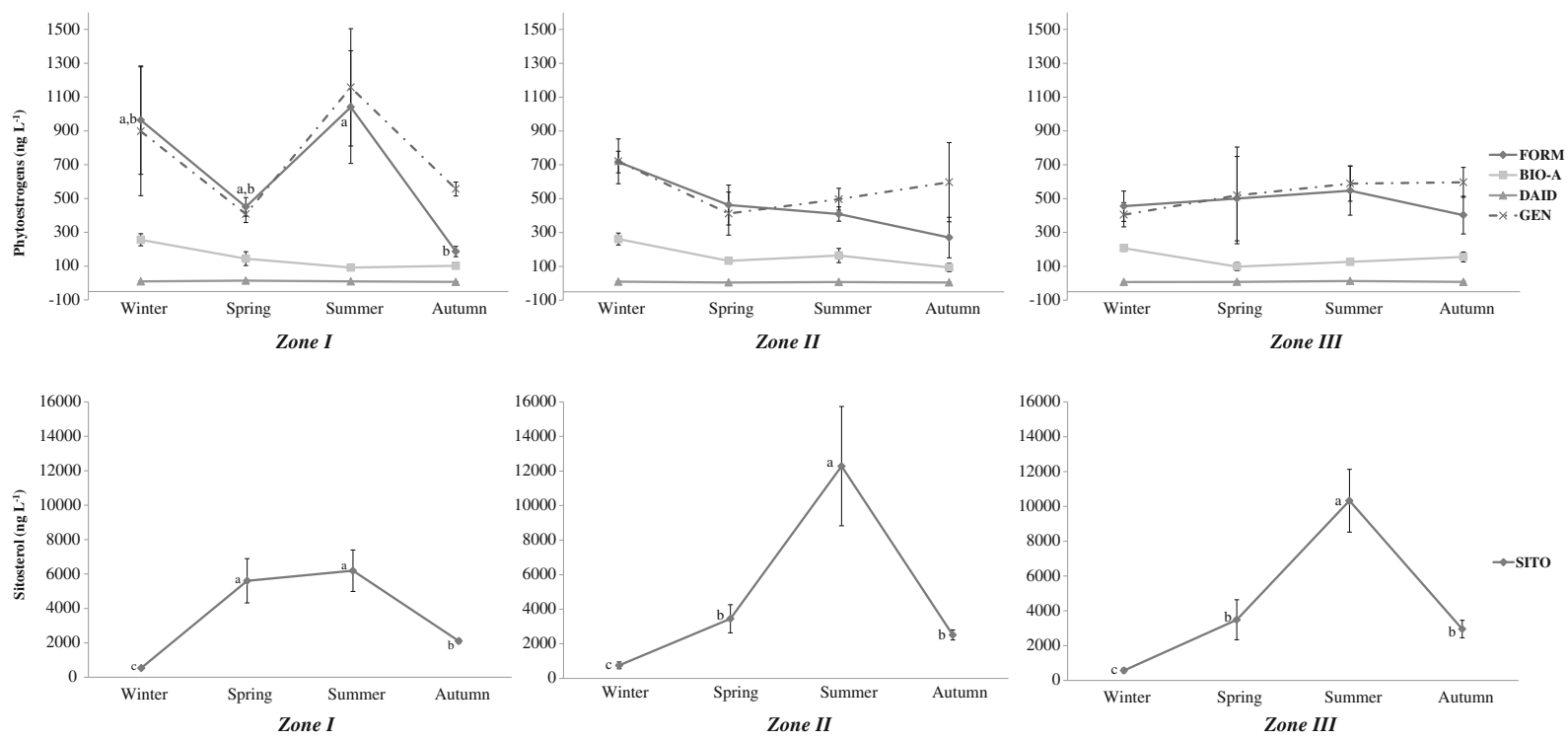

Fig. 5 Spatial and seasonal fluctuations of several phytoestrogens and SITO at Zones I, II and III of Ria Formosa Lagoon. Data is shown as mean \pm standard error of the mean $(\mathrm{SE}) ; n=3$ for each zone in winter and spring and $n=6$ in summer

Industrial compounds

Figure 4 show the annual fluctuation of nine industrial compounds (APEOs, APs, and BPA) which frequency, in all analyzed samples, was $100 \%$. These pollutants were ubiquitous in the Ria Formosa Lagoon and likely to estrogens, no significant differences $(p>0.05)$ were found among zones. Amongst these compounds the APEOs were the most abundant industrial ones $(p<0.001$; Table 2) reaching, at all sampling sites, amounts of approx.
$800 \mathrm{ng} \mathrm{L}^{-1}$ for the NPEOs and $100 \mathrm{ng} \mathrm{L}^{-1}$ for OPEOs in spring and summer, occasions when NP2EO increased significantly all zones ( $p<0.05$; Fig. 4$)$. Considering the APs, 4-NP was the most abundant alkylphenol $(\mathrm{p}<0.001$; Fig. 4) attaining, even at Zone II, concentrations of $\approx 511$ ng $\mathrm{L}^{-1}$ in summer. The other APs, namely 4-t-OP, 4-OP and 4-n-NP, showed significant lower amounts $(p<$ 0.001; Fig. 4) than those reported for 4-NP (Table 2). Considering the total amounts of the mentioned APs, per zone, their concentrations ranged from $24 \mathrm{ng} \mathrm{L}^{-1}$ at

Table 3 Physico-chemical parameters evaluated locally in each sampling zone from February to December 2010

\begin{tabular}{|c|c|c|c|c|c|c|c|c|c|c|}
\hline Season & Zone & $\mathrm{pH}$ & $\mathrm{T}\left({ }^{\circ} \mathrm{C}\right)$ & Salinity & $\begin{array}{l}\text { Dissolved O2 } \\
\mathrm{mg} \mathrm{L}^{-1}\end{array}$ & $\begin{array}{l}\mathrm{NO}_{2}^{-} \\
\mathrm{mg} \mathrm{L}^{-1}\end{array}$ & $\begin{array}{l}\mathrm{NO}_{3}^{-} \\
\mathrm{mg} \mathrm{L}^{-1}\end{array}$ & $\begin{array}{l}\mathrm{NH}_{4}^{+} \\
\mathrm{mg} \mathrm{L}^{-1}\end{array}$ & $\begin{array}{l}\text { Un-ionized } \mathrm{NH}_{4}^{+} \\
\mathrm{mg} \mathrm{L}^{-1}\end{array}$ & $\begin{array}{l}\mathrm{PO}_{4}{ }^{3-} \\
\mathrm{mg} \mathrm{L}^{-1}\end{array}$ \\
\hline \multirow[t]{3}{*}{ Winter } & I & $8.2 \pm 0.2$ & $16.7 \pm 0.2$ & $33.8 \pm 0.3$ & $7.6 \pm 0.0$ & $0.03 \pm 0.0$ & $0.5 \pm 0.1$ & $0.8 \pm 0.1$ & $0.06 \pm 0.01$ & $0.07 \pm 0.0$ \\
\hline & II & $8.2 \pm 0.2$ & $15.2 \pm 1.8$ & $27.6 \pm 2.7$ & $9.9 \pm 0.1$ & $0.03 \pm 0.0$ & $0.5 \pm 0.2$ & $0.8 \pm 0.1$ & $0.05 \pm 0.01$ & $0.02 \pm 0.0$ \\
\hline & III & $8.3 \pm 0.1$ & $15.3 \pm 7.6$ & $21.6 \pm 11.7$ & $8.8 \pm 0.1$ & $0.02 \pm 0.0$ & $1.0 \pm 0.4$ & $0.5 \pm 0.1$ & $0.04 \pm 0.01$ & $0.03 \pm 0.0$ \\
\hline \multirow[t]{3}{*}{ Spring } & I & $8.2 \pm 0.7$ & $18.6 \pm 0.2$ & $35.7 \pm 0.2$ & $8.1 \pm 0.1$ & $0.01 \pm 0.0$ & - & $0.3 \pm 0.1$ & $0.15 \pm 0.05$ & $0.08 \pm 0.1$ \\
\hline & II & $8.2 \pm 0.1$ & $17.9 \pm 2.2$ & $32.1 \pm 3.0$ & $8.7 \pm 0.0$ & $0.02 \pm 0.0$ & - & $0.3 \pm 0.2$ & $0.17 \pm 0.10$ & $0.02 \pm 0.1$ \\
\hline & III & $8.3 \pm 0.2$ & $17.9 \pm 9.4$ & $26.4 \pm 13.9$ & $8.7 \pm 0.0$ & $0.01 \pm 0.0$ & - & $0.6 \pm 0.2$ & $0.30 \pm 0.12$ & $0.02 \pm 0.1$ \\
\hline \multirow[t]{3}{*}{ Summer } & I & $8.3 \pm 0.9$ & $26.3 \pm 0.5$ & $37.2 \pm 0.6$ & $8.9 \pm 0.1$ & $0.01 \pm 0.0$ & $0.1 \pm 0.0$ & $0.5 \pm 0.3$ & $0.04 \pm 0.03$ & $1.13 \pm 0.3$ \\
\hline & II & $8.2 \pm 0.6$ & $26.2 \pm 1.9$ & $34.0 \pm 2.7$ & $10.2 \pm 0.1$ & $0.02 \pm 0.0$ & $0.3 \pm 0.2$ & $0.3 \pm 0.1$ & $0.03 \pm 0.01$ & $1.60 \pm 0.4$ \\
\hline & III & $8.2 \pm 1.0$ & $25.6 \pm 2.1$ & $30.1 \pm 2.0$ & $9.9 \pm 0.1$ & $0.02 \pm 0.0$ & $0.4 \pm 0.3$ & $0.2 \pm 0.1$ & $0.02 \pm 0.01$ & $1.40 \pm 0.4$ \\
\hline \multirow[t]{3}{*}{ Autumn } & I & $8.3 \pm 1.3$ & $17.5 \pm 0.5$ & $34.5 \pm 0.7$ & $8.1 \pm 0.1$ & $0.02 \pm 0.0$ & $0.4 \pm 0.0$ & $0.7 \pm 0.1$ & $0.03 \pm 0.01$ & $0.06 \pm 0.0$ \\
\hline & II & $8.4 \pm 0.7$ & $17.5 \pm 3.7$ & $31.9 \pm 5.3$ & $7.8 \pm 0.1$ & $0.04 \pm 0.0$ & $0.4 \pm 0.1$ & $3.0 \pm 1.3$ & $0.26 \pm 0.12$ & $0.13 \pm 0.1$ \\
\hline & III & $8.4 \pm 0.8$ & $17.1 \pm 4.2$ & $26.0 \pm 6.8$ & $7.5 \pm 0.1$ & $0.03 \pm 0.0$ & $1.0 \pm 0.3$ & $1.5 \pm 0.6$ & $0.12 \pm 0.06$ & $0.27 \pm 0.2$ \\
\hline
\end{tabular}

Data is presented as mean \pm standard error of the mean (SE) 
Zone I to $29 \mathrm{ng} \mathrm{L}^{-1}$ at Zone II. Considering the industrial compounds, APEOs and APs together as one group of industrial pollutants their levels increase significantly in summer at all zones $(p<0.001)$. Likely to APEOs and APs, BPA was always present in all zones in concentrations that were statistically equivalent either among zones or seasons (Fig. 4).

Phytoestrogens and sitosterol

Phytoestrogens, namely FORM and GEN, showed a seasonal pattern of fluctuation at Zone I (Fig. 5) with a clear peak in summer, occasion when these compounds attained more than $1,000 \mathrm{ng} \mathrm{L}^{-1}$. At Zones II and III this pattern was not observed but the amounts of the last two compounds were always higher than those of BIO-A $\left(\approx 150 \mathrm{ng} \mathrm{L}^{-1}\right)$ and DAID $(\approx 8 \mathrm{ng}$ $\left.\mathrm{L}^{-1}\right)$. Concerning SITO, it was observed a clear seasonal pattern of fluctuation with a significant rose $(p$ $<0.001$; Fig. 5) at all zones in summer. At Zone II, the levels of SITO reached the highest amounts attaining more than $12,000 \mathrm{ng} \mathrm{L}^{-1}$ (Table 2). The frequency of all measured phytoestrogens in the analyzed samples was close to $100 \%$ and that of SITO was $100 \%$.

Physicochemical parameters

All analyzed physico-chemical parameters are shown in Table 3. Concerning the annual average levels of nitrates $\left(\approx 0.5 \mathrm{mg} \mathrm{L}^{-1}\right)$, nitrites $\left(\approx 0.02 \mathrm{mg} \mathrm{L}^{-1}\right)$, ammonia $\left(\approx 0.8 \mathrm{mg} \mathrm{L}^{-1}\right)$, un-ionized ammonia $\left(\approx 0.1 \mathrm{mg} \mathrm{L}^{-1}\right)$, and phosphates $\left(\approx 0.4 \mathrm{mg} \mathrm{L}^{-1}\right)$ no differences were found among the studied zones. The annual average amounts of dissolved oxygen (DO) were $\approx 8.7 \mathrm{mg} \mathrm{L}^{-1}$, and signs of hypoxia were never observed at any site or occasion. In Table 3 it is also referred the annual values of temperature, $\mathrm{pH}$, salinity and conductivity.

\section{Discussion}

Natural and pharmaceutical estrogens

The main inputs of estrogens such as E1, E2 and EE2 into aquatic environments are human and animal excretion, the major sources of which are the WWTPs effluents. Herein, the area is impacted by the effluents coming from the 28 WWTPs (Ferreira 2003), among which some, at least 12 , are located close to the coastline. These WWTPs are known to have several functional problems (Mudge et al. 1999; Hopkins and Mudge 2004; Mudge and Bebianno 1997), which together with the direct discharges coming from innumerous recreational boats and non-treated sewages, contribute to the estrogenic load of the area. Along with the last compounds the annual amounts of EE2 were always significantly higher than those of E1 and E2, which is in accordance knowledge that synthetic hormones are more stable in water than natural hormones (Mes et al. 2005). In summer, occasion when the number of inhabitants of this area increases almost three times comparatively to those in winter (Mudge and Bebianno 1997), it was possible to observe an almost twofold increase of both EE2 and E2 levels at both Zones II and III. Thus, in spite of the visual attractive attributes of the Ria Formosa Lagoon, the fact is that the global annual amounts of E1, E2 and EE2, measured at the all sampling zones $\left(\approx 30 \mathrm{ng} \mathrm{L}^{-1}\right.$ in summer), confirm that these EDCs are in amounts able of inducing estrogenic effects in fish, such as vitellogenesis and feminization, which, have been proved to produce negative impacts on the long term sustainability of wild areas (Jobling and Tyler 2003). Other animals can be affected, including bivalves that are utterly important for the local economy. Not far from the Ria Formosa, feminization phenomena in clams, Scrobicularia plana, were recently reported (Gomes et al. 2009). Besides, since it exits a possible linkage between these chemicals and several human endocrine disorders (Safe 2000), the local condition of Ria Formosa is endanger since the assayed areas are considered clean zones, accordingly to the Directive 76/160/CEE and the Portuguese legislation (DR No. 176-1-8-1998), and are used all year long by local inhabitants, and seasonally by a huge number of tourists, for recreational purposes (fisheries, baths, boat trips, water sports) and as an important source of fish and shellfish farming.

Industrial pollutants

The APEOs, known to be able to promote estrogenic effects on both wild fauna and humans (Safe 2000; Zoller 2006), were the most abundant industrial pollutants measured at all zones of the lagoon. In spite of APEOs were banned from Europe in 2003 (Directive 
2003/53/EC 2003), exactly due to their activity as endocrine disrupters, their presence was still ubiquitous in the lagoon. Its origin was uncertain, however it is known that this zone has been polluted by metallurgic industries that represent $25 \%$ of the industrial production of the Ria Formosa area (Maria et al. 2009; Serpa et al. 2005) and are associated to the usage of APEOs. Herein, the APEOs reached maximal values in summer, occasion when their levels increased significantly in all assayed zones (Fig. 4) attaining amounts that are similar to those found in other Portuguese, Spanish and Greek coastal waters (David et al. 2009; Rocha et al. 2012a, b; Arditsoglou and Voutsa 2008). This observation suggests these compounds are still being used and thus constitute a wide global problem of several coastal areas (Soares et al. 2008). The increase of APEOs in summer can be probably due to the scarcity of water from several riversides that usually supply the lagoon with fresh water and thus possibly dilute these chemicals in the channels; nonetheless further studies are needed to confirm this hypothesis. Once in the environment, the APEOs degrade within one or two days, deriving APs (NPs and OPs), which are much more harmful and persistent than their parents (Safe 2000). Herein, the fluctuation patterns of the NPs and OPs were consistently and close related to those of the NPEOs and OPEOs (Fig. 4) and thus their levels were also higher in summer, occasion when the concentrations of the NPs reach $500 \mathrm{ng} \mathrm{L}^{-1}$ and those of OPs $16 \mathrm{ng} \mathrm{L}^{-1}$. Since these amounts were always higher than $10 \mathrm{ng} \mathrm{L}^{-1}$, established by European regulations as the maximal value allowed in surface waters for these EDCs (Erickson 2002), it is concluded that both protection and depollution measures are needed in the Ria Formosa Lagoon. Also BPA, systematically measured at all sites (ca. $30 \mathrm{ng} \mathrm{L}^{-1}$ ), was demonstrated to be a ubiquitous compound of this lagoon, where their amounts were similar to those refereed in other surface waters, either in Portugal (Azevedo et al. 2000; Quirós et al. 2005), Spain (Céspedes et al. 2005), or The Netherlands (Vethaak et al. 2002). These observations suggest a chronic action of this compound over the local fauna, which may also trigger serious endocrine dysfunctions in local fauna (Crain et al. 2007). It is also important to stress that all the last referred compounds are highly hydrophobic and so they are able to adsorb to sediments and particulate matter, where their concentrations may even attain higher levels.
Phytoestrogens and sitosterol

Isoflavones are nonsteroidal naturally occurring compounds of plants. Among these chemicals, the BIO-A, GEN, FORM and DAID have affinity to the estrogenic receptors (Benassayag et al. 2002). However, since they show $\mathrm{EC}_{50}$ values that are three to four orders of magnitudes higher than that of E2 (Hoerger et al. 2009), the (total) concentration of the last compounds must be at least 1,000-fold higher than that of E2, i.e., in $\mu \mathrm{g} \mathrm{L} \mathrm{L}^{-1}$ range, to produce an estrogenic effect equivalent to that of E2 (Hoerger et al. 2009). In the environment, the sources of phytoestrogens are complex, but it is known that the aquatic flora of the Ria Formosa Lagoon is abundant in seagrass, Zostera noltii, mainly in the intertidal area (Guimaraes et al. 2012), and that the lagoon margins are the habitat of plants such as Typha sp., Tamarix african, Phragmites communis, Juncus acutus, Fuirena pubescens, Carex riparia and Carex hispida, Cladium mariscus, Callitriche stagnalis, and Potamogeton spp. Some of these species were already been identified as having considerable amounts of phytoestrogens (Mackova et al. 2006). In fact, close to the important natural area of Ludo (Zone I), it was possible to observe a seasonal pattern of fluctuation for both FORM and GEN, the amounts of which were always higher than the other isoflavones. Comparing the present values with those reported for other Portuguese aquatic habitats, it is observed that levels of FORM, DAID, and GEN were in the Ria Formosa Lagoon about three to twelve fold higher than those observed in the North of Portugal (Rocha et al. 2012b). This fact suggests that the different flora between these regions justifies these observations. Furthermore, because sometimes GEN alone attained concentrations that surpass $1,000 \mathrm{ng} \mathrm{L}^{-1}$, it is possible that estrogenic endocrine disruption may be induced locally by this phytoestrogen, as reported by others (Kiparissis et al. 2003). Endocrine disruption can also be induced by the phytosterol SITO, which is structurally similar to cholesterol. This natural compound can cause endocrine disruption either by decreasing the availability of cholesterol to the P450scc, enzyme involved in the conversion of that hormone to pregnenolone, or by decreasing the activity of this enzyme (Kime 1998). In the past, SITO was identified as an important component of vascular plants and seeds (Benassayag et al. 2002) but more recently it was also linked to the presence of seagrass (Volkman et al. 2008), which is very abundant in this area. The 
observation of huge amounts of seagrass and available amounts of organic matter (Volkman et al. 2008) agrees with the presence of WWTPs in the studied area. Thus, and likely to the other EDCs, mainly APs and APEOs, SITO was measured in considerable amounts, mainly at Zone II, in summer (up to $12,300 \mathrm{ng} \mathrm{L}^{-1}$ ). This observation is quite worrying since when SITO concentrations surpass $10,000 \mathrm{ng} \mathrm{L}^{-1}$ it can act as an endocrine disrupter for aquatic animals (Clotfelter et al. 2010).

\section{Physico-chemical data}

Some physico-chemical parameters closely related to sewage and WWTPs discharges ( $\mathrm{pH}$, dissolved oxygen, ammonium, nitrites, nitrates, and phosphates) were additionally evaluated in the Ria Formosa Lagoon. Herein, the levels of DO were always higher than $8 \mathrm{mg} \mathrm{L}^{-1}$, even in summer when average temperatures are very high $\left(>25^{\circ} \mathrm{C}\right)$, and so the hypoxia described in previous studies (Newton et al. 2010) was never observed in the present one. Unfortunately, the other parameters strongly proved that the water quality of the Ria Formosa Lagoon was worse in 2010 than reported in the past (Falcão et al. 2003). In fact, herein the amounts of toxic (un-ionized) ammonia, which is dependent of both $\mathrm{pH}$ and temperature, attained almost $0.4 \mathrm{mg} \mathrm{L}^{-1}$ in summer, value that was defined as hazardous by the Water Quality Criteria (Environmental Studies Board, National Academy of Sciences, 1972). Additionally, the total amounts of phosphorous, which WWTPs and organophosphorus pesticides are the most common sources, were also measured in excessive amounts in summer at all the studied sites, i.e., up to ten fold higher than the maximal concentrations of $0.1 \mathrm{mg} \mathrm{L}^{-1}$ recommended for rivers and streams by the Water Quality Criteria (Environmental Studies Board, National Academy of Sciences, 1972).

\section{Conclusions}

The present study identified the presence of natural and pharmaceutical estrogens, APs, APEOs, phytoestrogens and SITO along the Ria Formosa Lagoon suggesting that these compounds are ubiquitous rather than a result of sporadic discharges. The entire lagoon is similarly impacted by the last chemicals which in some occasions attained concentrations able to induce endocrine disruption. In particular, EE2, NP and SITO reached in summer, when water temperatures are high, concentrations that may trigger endocrine disruption in local fauna and pose risks for humans either directly (bathing) or indirectly by the uptake of contaminated seafood (fish and shellfish). This occurrence is even more worrying when all EDCs are considered as a cocktail of compounds, which action can be foreseen as being potentially more deleterious than that of individual compounds. This observation agrees with findings of endocrine disruption in local aquatic species. Also the physico-chemical data corroborates with the present chemical monitorization, further proving that the Ria Formosa Lagoon is being highly impacted by anthropogenic sources. Thus, local depollution measures are needed since Portugal, as a member of the EU, has adopted the European legislation which aims to prevent, protect and improve the quality of the environment, the protection of the human health and the rational and cautious use of natural resources. Our study calls the attention for the need of active toxicological monitoring even of protected areas, often assumed by authorities and the general public as pristine and safe.

Acknowledgments This work was financially supported by FEDER funds through the Competitiveness and Trade Expansion Program - COMPETE and by National Funds provided by Fundação para a Ciência e a Tecnologia (FCT), via the project PTDC/MAR/70436/2006. Acknowledgements are also due to the Administração da Região Hidrográfica do Algarve I.P (AHR-Algarve, Portugal) that provided us important technical information about the Ria Formosa Lagoon and to Francisco Arenas Parra and Carolina Caldas for their help in statistics and water processing, respectively.

\section{References}

Newton, A., \& Mudge, S. M. (2003). Estuarine, Coastal and Shelf Science, 57, 73-85.

Calixto, V. F. C., Alves, J., Botelho J. (2011). In Boletim Informativo - Newsletter, ed. Sociedade Polis Litoral Ria Formosa (info@polislitoralriaformosa.pt), Olhão, Portugal, pp. 1-12.

Ferreira, J. G., Simas, T., Nobre, A., Silva, M. C., Shifferegger, K., Lencart-Silva, J. (2003). In Identification of sensitive areas and vulnerable zones in transitional and coastal Portuguese systems. Application of the United States National estuarine eutrophication assessment to the Minho, Lima, Douro, Ria de Aveiro, Mondego, Tagus, Sado, Mira, Ria Formosa and Guadiana systems, ed. INAG and IMAR, pp. 1-151.

Bebianno, M. J., \& Barreira, L. A. (2009). Ecotoxicol and Environmental Safety, 72, 1849-1860. 
Carvalho, P. N., Rodrigues, P. N. R., Basto, M. C. P., \& Vasconcelos, M. (2009). Chemosphere, 75, 595-600.

Vasconcelos, P., Gaspar, M. B., \& Barroso, C. M. (2010). Journal of Environmental Monitoring, 12, 1823-1832.

David, A., Fenet, H., \& Gomez, E. (2009). Marine Pollution Bulletin, 58, 953-960.

Bebianno, M. J., Géret, F., Hoarau, P., Serafim, M. A., Coelho, M. R., Gnassia-Barelli, M., et al. (2004). Biomarkers: Biochemical indicators of exposure, response, and susceptibility to chemicals, 9, 305-330.

Dionisio, L. P. C., Rheinheimer, G., \& Borrego, J. J. (2000). Marine Pollution Bulletin, 40, 186-193.

Gamito, S. (2008). Estuarine, Coastal and Shelf Science, 77, 710-720.

Mudge, S. M., Bebianno, M. J. A. F., East, J. A., \& Barreira, L. A. (1999). Water Research, 33, 1038-1048.

Newton, A., \& Mudge, S. M. (2005). Estuarine, Coastal and Shelf Science, 62, 405-414.

Newton, A., Oliveira, P. S., Icely, J. D., \& Foster, P. A. (2010). Journal of Environmental Monitoring, 12, 355-360.

Hoerger, C. C., Wettstein, F. E., Hungerbuhler, K., \& Bucheli, T. D. (2009). Environmental Science and Technology, 43, 6151-6157.

Clotfelter, E. D., McNitt, M. M., Carpenter, R. E., \& Summers, C. H. (2010). Fish Physiology and Biochemistry, 36, 933-943.

Rocha, M. J., Ribeiro, C., \& Ribeiro, M. (2011). International Journal of Environmental Analytical Chemistry, 91, 11911205.

Duarte, P., Azevedo, B., Guerreiro, M., Ribeiro, C., Bandeira, R., Pereira, A., et al. (2008). Hydrobiologia, 611, 115-132.

Ribeiro, C., Tiritan, M. E., Rocha, E., \& Rocha, M. J. (2007). Journal of Liquid Chromatography and Related Technologies, 30, 2729-2746.

StatSoft I.(2007). In Book STATISTICA (data analysis software system).

Hopkins, F. E., \& Mudge, S. M. (2004). Environmental Forensics, 5, 213-223.

Mudge, S. M., \& Bebianno, M. J. (1997). Marine Pollution Bulletin, 34, 163-170.

Mes, T., Zeeman, G., \& Lettinga, G. (2005). Reviews in Environmental Science and Biotechnology, 4, 275-311.

Jobling, S., \& Tyler, C. R. (2003). Pure and Applied Chemistry, $75,2219-2234$.

Gomes, T., Gonzalez-Rey, M., \& Bebianno, M. J. (2009). Ecotoxicology, 18, 1104-1109.

Safe, S. H. (2000). Environmental Health Perspectives, 108, 487-493.

Zoller, U. (2006). Environmental International, 32, 269-272.

D. 2003/53/EC (2003). In Book of the amending for the 26th time Council Directive 76/769/EEC relating to restrictions on the marketing and use of certain dangerous substances and preparations (nonylphenol, nonylphenol ethoxylate and cement),ed. Official Journal of the European Union, pp. L178/24-L178/27.

Maria, V. L., Santos, M. A., \& Bebianno, M. J. (2009). Comparative Biochemistry and Physiology. Toxicology \& Pharmacology, 150, 196-208.

Serpa, D., Jesus, D., Falcão, M., Cancela da Fonseca, L.(2005). In Ria Formosa ecosystem: socio-economic approach., ed. IPIMAR, (http://ipimar-iniap.ipimar.pt), 28, pp. 1-50.

Rocha, M. J., Cruzeiro, C., Ferreira, C., \& Rocha, E. (2012a). Toxicological and Environmental Chemistry, 94(2), 252-261.

Rocha, M. J., Ribeiro, R., Ribeiro, C., Couto, C., \& Rocha, E. (2012b). Toxicological and Environmental Chemistry, 94(2), 262-274.

Arditsoglou, A., \& Voutsa, D. (2008). Environmental Pollution, 156, 316-324.

Soares, A., Guieysse, B., Jefferson, B., Cartmell, E., \& Lester, J. N. (2008). Environmental International, 34, 1033-1049.

Erickson, B. E. (2002). Environmental Science and Technology, $36,140-145$.

Azevedo, D., Lacorte, S., Viana, P., \& Barceló, D. (2000). Chromatographia, 53, 113-118.

Quirós, L., Céspedes, R., Lacorte, S., Viana, P., Raldúa, D., Barcelò, D., et al. (2005). Environmental Toxicology and Chemistry, 24, 389-395.

Céspedes, R., Lacorte, S., Raldúa, D., Ginebreda, A., Barceló, D., \& Piña, B. (2005). Chemosphere, 61, 1710-1719.

Vethaak, A. D., Lahr, J., Kuiper, R. V., Grinwis, G. C. M., Rankouhi, T. R., Giesy, J. P., et al. (2002). Toxicology, 181, 147-150.

Crain, D. A., Eriksen, M., Iguchi, T., Jobling, S., Laufer, H., LeBlanc, G. A., et al. (2007). Reproductive Toxicology, 24, 225-239.

Benassayag, C., Perrot-Applanat, M., \& Ferre, F. (2002). Journal of Chromatography B, 777, 233-248.

Guimaraes, M., Cunha, A. H., Nzinga, R. L., \& Marques, J. F. (2012). Journal for Nature Conservation, 20, 30-40.

Mackova, Z., Koblovska, R., \& Lapcik, O. (2006). Phytochemistry, 67, 849-855.

Kiparissis, Y., Gordon, C. B., Metcalfe, T. L., \& Metcalfe, C. D. (2003). Environmental Health Perspectives, 111, 11581163.

Kime, D. E. (1998). In Endocrine disruption in fish, ed. Springer, City.

Volkman, J. K., Revill, A. T., Holdsworth, D. G., \& Fredericks, D. (2008). Organic Geochemistry, 39, 689-710.

Falcão, M., Fonseca, L., Serpa, D., Matias, D., Joaquim, S. (2003). In Development of an information technology tool for the management of European southern lagoons under the influence of river-basin runoff. Synthesis Report Ria Formosa, ed. INIAP/IPIMAR - National Research Institute for Fisheries and Sea City, pp. 1-38. 